\title{
The Agenda Setting of Corona: Analysis of The Corona Dissemination Impact on The Community
}

\author{
${ }^{1}$ Muhammad Qadaruddin Abdullah, ${ }^{2}$ Nahrul Hayat, ${ }^{3}$ Abd. Rahman \\ Institut Agama Islam Negeri Parepare, Kota Pare-Pare, Sulawesi Selatan, Indonesia \\ E-mail: ${ }^{1}$ muhammadqadaruddin@stainparepare.ac.id, ${ }^{2}$ nahrulhayat@iainpare.ac.id, ${ }^{3}$ abdrahman@iainpare.ac.id
}

\begin{abstract}
This study is based on news dissemination about the Corona Virus Disease 2019, COVID-19, as a global pandemic. The massive amount of coronavirus news dissemination provokes the audiences to behave inappropriately. This study uses the theory of agenda-setting, which elaborates on the process of forming opinion in national television media. After that, the theory of media exposure is used to analyze the impact of exposure to the COVID-19 dissemination on social media. The research method used is a combination of qualitative and quantitative methods, namely, survey and interview in social media that is on the WhatsApp group of students and lecturers in the Province of South Sulawesi. The results of this study; First, the process of forming an opinion by the public media has not done proportionally, the information dissemination of the coronavirus had covered the dissemination of other important cases, such as the legal and corruption issues. Second, the effect of the COVID-19 news dissemination on social media not only had an impact on people's health but also a multi-effect toward the economic, religious, and psychological condition. The multi-dimensional impacts are responsible for setting the exposure of COVID-19 news dissemination as the single issue that makes the diversion of opinion and other issues occurred, such as legal and corruption cases which are no longer being a public talk.
\end{abstract}

Keywords: COVID-19 News, Public Opinion, Media Exposure, Media Effects

\section{INTRODUCTION}

The increased number of COVID-19 cases since March 2020 had the government to impose appealing policies from practicing the physical distancing to the enforcement of national/local quarantine. The implementation of these policies leads to the occurrence of the instability of the society and a significant decrease in the economy of Indonesia since the companies no longer perform their production activities and they experienced difficulties in the payment of debts. The household consumption in Indonesia also plummeted by $3.2 \%$ to $1.6 \%$ from around $5 \%$. There has been a shortage of food in the community. This figure is far from the APBN (National Expenditure and Spending Budget) target in 2020, which sets the growth of the APBN is $5 \%$, reported by Kompas. com. The community also demanded the government to provide protection and food security as the effects of Social Distancing/Physical Distancing as well as the welfare of the community amid this outbreak.

The news dissemination of the coronavirus had graced the social media, the community was presented with the massive news dissemination of the coronavirus that makes it as the public conversation. Some consider that as a misfortune while others take it as humor. Ironically, few also use the moment to spread hoaxes about coronavirus and face mask business. In social media, especially on YouTube, we can see the prank content 
regarding coronavirus that causing public unrest, some people blaspheme the maker of the video in using such tragedy as the materials of a joke, game, and laugh at the suffering of people.

Social media, YouTube, Tiktok app, and other media are some of the tools that can be used to prevent the spread of coronavirus information. The corona exposure, or also referred to as impactrelated corona information aims to make the public able to perform strategic steps against the virus. Some steps of preventing the spread of coronavirus are the use of masks, the restriction of outdoor activities, the cleanliness focuses, and the appearance of herbs which can maintain the immune system of the body. In addition to preventive measures, it is also required the strategic measures of the government in preventive, curative actions. The dissemination of the coronavirus in various social media, such as Facebook, YouTube, Instagram, and others leads the shift of attention from the issues of legal and politics into issues of health, economy, and religion.

On the other hand, the mass media also set the COVID-19 as the main content of the news. The mass media can be considered as the source of information regarding the events that are happening in all parts of the world. The presence of the mass media is considered able to perform its functions, in this case, to inform or to educate. In Article $28 \mathrm{~F}$ of 1945 CONSTITUTION, it is explained that every person has the right to communicate and obtain information to develop personal and social environment, as well as the right to seek, obtain, possess, store, process, and convey information by using all available channels. The audiences tend to be more active looking for what they want, and what is currently popular in the media because the media presents the issues that should be known by the audiences.
The audiences are easily influenced by the contents that are delivered both on television and in social media (consumers of information), both the producer and the audiences have a mutual influence on one another. Media production has reconstructed the content (Nugroho, 2015). Conceptually audiences consume media in a variety of ways and purposes. This refers to the perception that emphasis on personal subjective experience (meaning construction) in understanding a phenomenon. In this context, a closer identification of what happens on the individual as a user of the text media and how they perceive and understand the text of the media when dealing with the media. Since the audiences are unique creatures, they can act on two sides that are active and passive when confronted with the mass media.

The media and the audience build a mutual relationship in which the media produces content according to the tastes of the audience, while the audience needs the media to be the sources and as a medium of information, the audience is always selective in receiving information (Rulli,2018). In this case, the media and the audience are the concepts that are considered crucial in the study of media. As one of the most important elements in the process of mass communication, it is associated with the emergence and development of media effects study.

The media is needed to help the Indonesian community to be calm in encountering the issue of the corona. It is expected that the media can affect the audience by not provoking messages that make people more anxious because the audience is potentially reactive on what the media presents. As Baran and Davis argued that active community is not focused on what is disseminated by the media, but they are focused on what they think about the information conveyed by the media (Puji,2016). Thus, in this 
case, the role of the media can be as an anxiety breaker on the issue of corona's by framing the message to be more humane and persuasive so that what is produced by the media can be accepted proportionally, and the audience can filter the information conveyed by the media.

The use of media by the audiences can be categorized into several needs based on the classification presented by McQuail. Firstly, the media became a diversion tool or a means of entertainment letting the audiences out of their everyday routine; Secondly, the media becomes a tool that can replace the position of friends (personal relationships); Thirdly, the media works as a personal identity or becomes the decisive social strata of the person, the more expensive the media used, the higher social strata of the person; Fourthly, the media works as the surveillance. (Puji,2016)

Media as a source of information should be able to convince the people of Indonesia to be not afraid and fight the spread of the coronavirus together, as well as give the message which is instructive against the virus, to reduce the anxiety feeling that will affect the state of the audience's psychic.

\section{Agenda Setting}

One of the theories that will explain how the mass media influences the audiences is the theory of agenda setting. The agenda setting assumes that the media can determine what is considered important by the public. (Little John, 1996). The agenda setting is a linear process that consists of three stages. Firstly, the media agenda is a form of policy from the editor of the media. Secondly, the media agenda that in some ways affects the mental attitude of the public towards the importance of an issue is called the public agenda, which will affect the policy agenda. Third, the policy agenda is what the policymakers of public policy are considered in compliance with the one considered important by the public. In other words, the media agenda can determine the public agenda and government policy.

Among the previous studies that use agenda setting as a framework of theoretical research is Melta Natalia who analyzed the influence of the agenda setting on the dissemination of Pedophilia news in Samarinda Post. Natalia found that the strategy of agenda setting on Samarinda Post successfully had the parents of the victims of a pedophile for daring to report his son's case to the authorities (Natalia, 2017). In 2011, Ansor researched the relevance of the agenda setting theory and image of the government. Ansor in his research confirmed the thesis that the way the media convey the reality (Ansor,2011)

\section{Media Exposure}

Media exposure is the process of listening to, viewing, and reading the information, as well as an experience of low or high attention of the audience. Media exposure deals with the attention level and the use of media in society (Ilham, 2014). If it is associated with the dissemination information about coronavirus then this theory tries to analyze the level of society's attention toward the news. The theory of media exposure will also analyze responses of the public on corona news dissemination, whether the news got a negative or positive response. (Amala,2019) In Media Exposure, the strong influence of the media depends on several factors, the factors will influence people's reactions to mass media.

The factors can be listed as follows: First, individual psychology that the individual affected by the condition and situation of the biological aspects, attitudes, values, beliefs, as well as the experiences; Second, every individual 
is affected by his/her interactional environment, regarding his/her social group; Third, the demographic factors such as age, gender, and education level. The age can be divided into three, namely (1) the unproductive age ranging from 0-14 years old, (2) the productive age ranging from 15-64 years old, and (3) The not-productive age starting from 65 years old. Gender is the division of society based on differences in the physical characteristic, social status, men, and women.

Furthermore, the level of education is a process of formal learning that has some levels ranging from the most basic namely early childhood education to the highest level, namely the doctoral level. The social category is the people at the same age and gender that tend to have the same response on the message delivered by mass media (Mustika,2019).

The research on media exposure conducted by Widiastuti about the extent of media influence in the disclosure of the CSR program also explained the importance of the dissemination of company activities since the company will get social pressure to put attention to the surrounding community. (Widiastuti,2017)

Based on the previous researches on the successful of agenda setting in revealing the pedophile behavior and in building the community perception on corruption, this research found out that the opinion shaped on Covid-19 has covered the news about corruption and legal cases. This current research is different from the previous ones, since in this research, the media put more priority on the issues about corona than the issues of corruption and legal cases. The media exposure has manipulated the public opinion, resulting on the negligence of corruption and legal case as the public opinion. The higher rate of frequency, duration, and usage of social media regarding the corona virus affect the psychological condition of the community, so the public attention on politic and legal case issues can be diverted to corona virus issue.

There are two purposes of this study. First, this study aimed to determine how the process of opinion formation of mass media related to corona since the researchers and the public can understand that there are so many blurred opinions after the dissemination of news about the corona; The second purpose was to determine the behavior of the public related to the dissemination of corona news so that the community can have the strategy to anticipate the impact of the dissemination of coronavirus news.

The opinion formation by the government related to Covid-19 has affected the economic, psychological, and religious sectors. The impact of information dissemination in the community have hindered the spread of important information, frequently discussed by the community, particularly the legal and corruption cases. Therefore, researchers formulated the research question of "How is the process of opinion formation and how are the impacts of opinion formation on the society?

\section{METHOD}

This research used a combination of quantitative and qualitative research methods, that simultaneously used during data collection. For example, researchers can conduct interviews with respondents as well as instruct them to fill out the questionnaire at the same time. This technique, according to Masri Singarimbun, is called semiquantitativequalitative. In this approach, the quantitative approach is the facilitator of the qualitative. (Kriyantono,2008) Between qualitative and quantitative, there will be no contradictions. Furthermore, in quantitative research, we will get the description, the narration, the qualitative 
explanation, that makes the quantitative research conducted is quantitative but some of the data analysis is qualitative. (Mulyana,2007)

The researchers distributed a survey to 100 existing samples in the WhatsApp group of lecturers and students in the Province of South Sulawesi. The survey was made in the Likert scale form and the researcher had a direct interview with the lecturers of the communication department about the process of opinion formation and direct interviews with the lecturers and students who were experiencing the impact of the COVID-19 news dissemination. Survey research is quantitative research. In survey research, the researcher made some questions to the respondents about their beliefs, opinions, characteristics of an object, and the past and present behavior (Sugiyono,2013). In addition to the survey, the researcher also conducted the interview which is a conversation with the purpose to find out more detailed information.

The conversation was conducted by two parties, namely the interviewer and interviewee; the purposes of the interview include constructing, projecting, verifying, changing, and extending the information obtained from other people. (Lexy,2010)

\section{RESULT AND DISCUSSION The Process of Opinion Formation by Television Media on Corona News}

In Indonesia, President Joko Widodo announced that two citizens of Indonesia were positively infected by the Corona and have Covid-19 on March 2, 2020. Suddenly all the media collectively highlight the announcement and massively spread it to the people of Indonesia. That event became the beginning of massive dissemination of Covid-19 news in various media platforms.

From the FIGURE 1, social media is the most widely used media in the dissemination of information, and of the social media, there was about $75.9 \%$ of the community received information about COVID-19. Mainstream media was in the second rank of media that was widely used by the community to get information, there were about $73,2 \%$ of the people who use the mainstream media to get information. The following is the opinion of a respondent regarding how the process of the formation of public opinion on coronavirus in Television,

"I think the media do not disseminate the COVID-19 news proportionally, the media only want to achieve a high rating for the program. There are still many

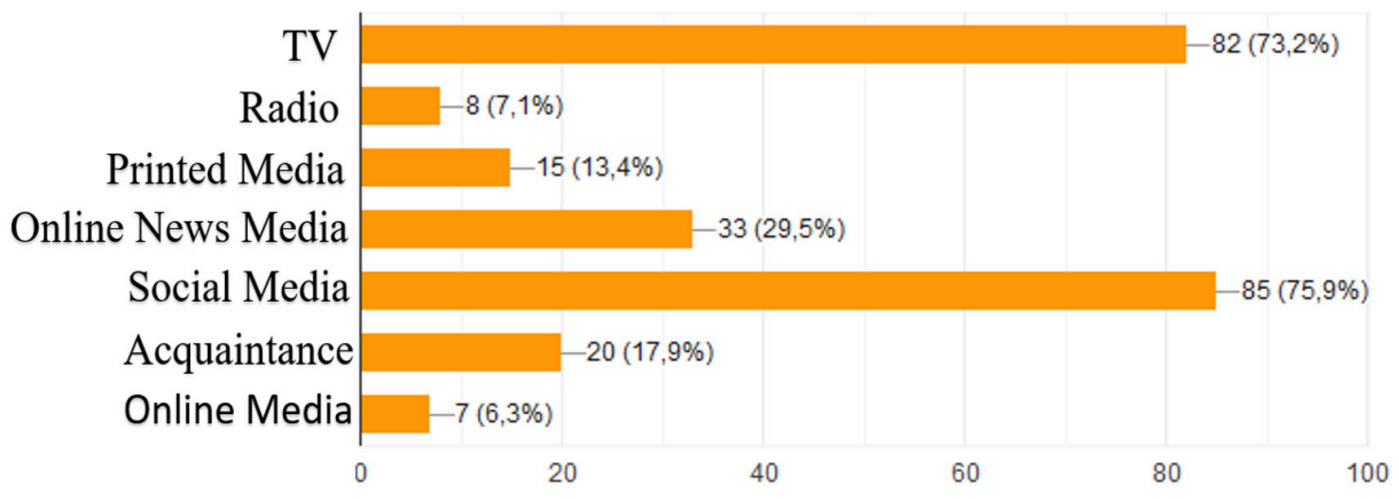

FIGURE 1: The Dissemination of Information about the Corona 


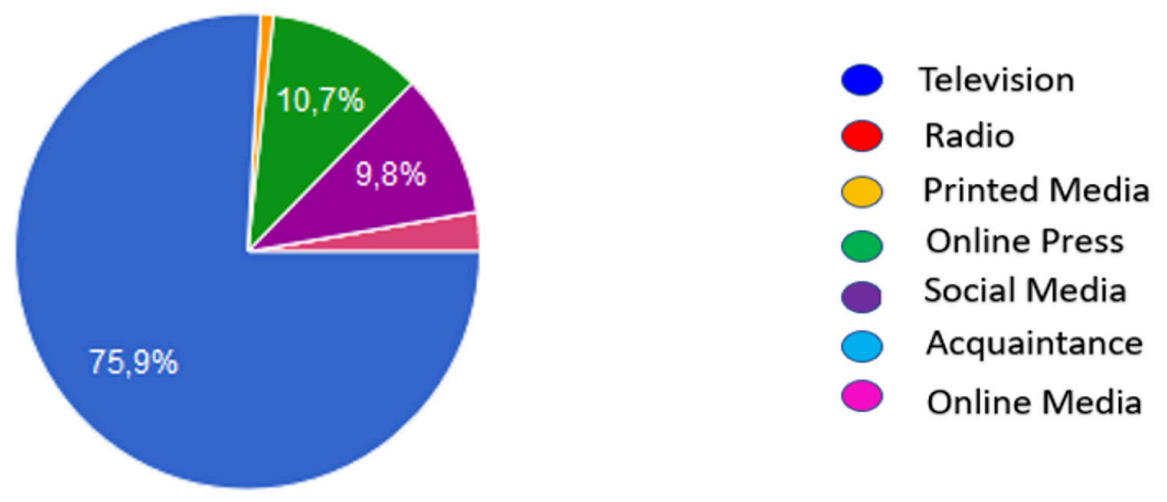

FIGURE 2. Level of Credibility Related to the Dissemination News of Coronavirus

other issues that are not reported" (Mifdah Hilmiah,2020).

In the theory of agenda-setting, in the process the formation of public opinion that beginning with the editor policy, the dissemination of the coronavirus news was considered as very important news, thereby affecting the policy of the editorial board of the media, the media assume that the news of the coronavirus was more interesting than the news of corruption, and the legislative policy. Therefore, social media and mass media produced more news dissemination about coronavirus.

The media exposure is a theory on the higher concerns, attention, and usage of social media in disseminating news since social media facilitates the easy way to share, produce contents and connect someone to others effortlessly (Munawwaroh, 2017)

\section{The Urgency of the Corona News}

Regardless of the health and the economic impacts that becomes the main coverage of the media, there is an interesting fact about dissemination news about coronavirus. In the perspective of mass communication study, mass media, such as television, radio, and newspapers, are the communication channels that most effectively disseminate information to the wider community. The study from
Nielsen Media Research in 2018 showed that the duration of watching television (TV) in Indonesian community was still high compared to the access of other media, that was an average of 4 hours 53 minutes per day, the duration of accessing the Internet became the second-highest that was an average of 3 hours 14 minutes per day.

Based on the FIGURE 2, social media is still the most in-demand media, but in terms of credibility, the Television, Newspaper, and Radio are still considered as the main and credible media. That is because the television media or the contemporary media has the Indonesian Broadcasting Commission (KPI), which always be the regulator and standards of the program broadcasting, whereas, in social media, there has been no regulation governing in the digital realm(Bianca Michelle Datubara,2019).

It shows that the dependence of information by Indonesian society on social media is still high. Furthermore, the media in the discourse of communication theory is seen as the fourth pillar of democracy who has the power of determining the dynamics of the political condition through public opinion (read: political communication). One of the theories that can explain this issue comprehensively is the theory of Agenda Setting.

The theory of Agenda Setting 
believes that the media can determine what is considered important by the public, in other words, the agenda of the media can determine the public agenda. The massive coverage of coronavirus issues explicitly become the main agenda of the news media in the last few weeks. The coronavirus suspects, the price of the mask, hoax, even the fraud regarding coronavirus simultaneously became the main content of the mainstream media in any program of their news. This, at first glance, is something considered normal due to the higher needs of information about corona by the community. According to one of the informant experts, the credibility of television media is more powerful than social media regarding the Covid-19 news.

"Indeed, the information about the coronavirus is important but the media grossly overestimate the portion of the news so that the other needs of information are not achieved. As it is known to the public from early March to July, the entire television reported COVID-19 news in every news program. Whereas television is more trusted by the public as a source of information compared to social media since social media is defenseless on the hoax" (Muh. Toufiq Syam,2020)

If we did a flashback to some point in pre corona time, then many public concerns were related to a series of issues being the news of media. For example, the drama of Aaron Masiku's investigation, the corruption case of stateowned enterprises Jiwasraya and Asabri, to recent one about the controversy of Omnibus Law.

The three issues when compared to the issue of Corona, have the same concerns on the public interest. Taking
Harun Masiku as an example. The figure that is the key in the law enforcement in criminal acts of corruption, even the coverage news of the case was quite high since it was dragging the name of the ruling party and the organizers of the elections in Indonesia. The corruption of state-owned enterprises Jiwasraya and Asabri, two cases of mega corruption that was estimated to make a dozen trillion rupiahs of state financial loss. If the corrupt money is used to "fight" Corona, it will be very beneficial, indeed. Since the Ministry of Health still complains of the number of hospitals in some big cities in Indonesia experience the lack of equipment testing and laboratory for the handling of the Corona.

Furthermore, the issue of the Priority Programs of the National Legislation of Regulation Drafting for Job Vacancy Creation (Cilaka Regulation Draft) was claimed by the government as the powerful Legislation to facilitate the investment procedures and is considered to be one of the strategies in the economic field. Nevertheless, not a few elites and experts reject this Regulation Draft because it is considered detrimental to low poor people, especially the bluecollar workers. Today's reality, the agenda of disseminating the three cases seems to be distracted by the "concern" on the Coronavirus. The news delivered by the government should not be just passed on the question of the state interests, however, it should be more on the public interest, in this case, as the information that public needs or as the basic needs of the community.(Kamil, 2018)

\section{The Crying Baby Effect}

The term of "crying baby" may still be unfamiliar to the public, while the denotative meaning is the "the baby is crying", the crying baby is a theoretical metaphor used by the author to describe the political and social phenomenon from 
the perspective of communication study (Hayat, 2019). The connotative meaning refers to the agenda-setting media which prioritizes the issue of corona while considering other important public issues.

Like crying babies, the people of Indonesia who were in the midst of economic difficulties had to postpone her crying because of the "dreaded-feared" by corona. Isn't the baby who was crying asking for milk on a " mother who has to go" can be pacified by the father to "scare" the baby?

The people are similar to a baby, hold the hunger, and wait for the milk of the Mother Earth. This symbolic meaning could be a critical perspective of the media behavior that is less proportional (read: mass communication) in the selection of issues (priming) and framing of information. We are all aware of the need for information about Corona, but the public is also entitled to receive quality information. The quality of Corona news dissemination is not measured by the extent to which the media can give a sense of fear and panic to the public, but more than that, the information of Corona should also accentuate the "calming" facts of the Corona.

The dissemination information about the number of recovered patients from the Corona not as much as the coverage of the mask price soaring. The surplus news about masks for example, which would potentially add to the sense of panic to the society. For instance, as of March 3, the number of people who recovered from Corona was 4.558, while the victims who died were 3.085 . We are more frequently listen to the news of the death than the healing case information that can be used as a reference for the public.

The next one, the information strategy of repression and the socialization of prevention is still much less than the news spread and the number of cases of new suspects. Beyond it all, the media should provide enough space for public issues, as exemplified earlier. The public also needs to keep an eye on the legal process concerning the people's money as a surveillance function of media (surveillance) in the book Media Effect and Society(Perse, 2001).

The media should be back to its social functions according to the existing regulations. The Press Act No. 40 of 1999 has been confirmed that in addition to as a means of dissemination of information, the media also serves as a means of education. Media coverage related to the Corona should be attached great importance to the dimensions of health education not a publication of the panic. The editor's kitchen of the media should refer back to the "recipe" of journalism that stated in the Ethics of Journalistic. Specifically, the medium of Television news should always operate based on the guidelines in the Guideline of Conduct of Broadcasting and Standards Broadcasting Program (P3SPS) determined by the Indonesian Broadcasting Commission.

Likewise, the principles of the Broadcasting Act No. 32 of 2002, which aims to serve the public's right to know, "the People's Right to Know". On the other hand, the public should also be able to translate the information wisely as warned by Peter Drucker, "The Most Important Thing in Communication Is Hearing What Isn't Said". Peter stated that hearing something that is not being informed by the media is also important.

\section{The Impact of Coronavirus on Behaviors Community}

News related to coronavirus not only affects the social behavior of the community but also the psychological condition such as panic buying, as well as the economy and tourism aspects. Regarding the psychological condition, the people experience the fear, that 
extends to the economy and tourism condition, for example, the economic conditions, based on data from the Central Statistics Agency (BPS) in January 2020, experienced a sharp decline in oil and gas and non-oil and gas exports by around $12.07 \%$.

The Head of Trade Assessment and Development Agency, Ministry of Trade, estimated that the economic growth had been slower by around $0.23 \%$. The implementation of the policy to ban tourist visits to Indonesia affected the company in hospitality, travel, and other entertainment industries, including a ban on the journey of pilgrims of umrah and hajj to Saudi.

\section{The Impact on Social Media}

Approach to the issue of the social media impact or effects is a change due to the audience having seen, read, or heard the content of the news from the media which will then affect the changes in attitude and knowledge of the audiences. It cannot be denied that the audience is individuals who are also active in responding to what is received from the media. As the opinion of McQuail that the audience is a society that can assess and interpret the messages delivered by the media, not just as passive individuals that accept the meaning which is produced by the mass media (Denis, 1997)

The communication style practice of modern society is now experiencing a revolution. The old society that was born in a period of ' 80 s and ' 90 s must have felt a significant difference. In the old society, after watching a television program, they will meet and gather to retell what they have been watched. Meanwhile, modern society will use social media as the place to tell the story of what they see, hear, and read from the media, which is known as the revolution in communicating in the modern era. Social Media is media that is composed of three parts, namely:
Infrastructure of information and the tools used to produce and distribute the media content. The media content can be in the form of private messages, news, ideas, and cultural products that are in digital form, then the producer and consumer of the media content in digital form are the individual, organization, and industry. Social Media is also a medium used by consumers to share text, images, sound, and video information (Rahadi,2017).

In the era of the communication revolution, many parties who do not want to miss the chance to share information that is happening in their social media channel. Social Media is a relatively new media that offer fast interactivity that becomes the magnet of interest for the millennial generation. As it was said by Flew: "New media is media that provide the digitization, convergence, interactivity, and development of the network in terms of the production and the delivery of messages. Ability in offering this relationship makes the users of the new media have the option of related information to be consumed, as well as the ability to control the information that is produced. This ability to offer a relationship that becomes the central concept of understanding the new media" (Erika, 2011)

The audience determines the access to the information that provided by new media in three ways, namely, when the information was accessed, what type of information will be accessed, and whether the audience was going to share (sharing) information that they get or not (Puji,2016). It can be said that modern society or famous as the millennial community is no longer becomes a consumer of the media contents but they tend to create its content at the same time.

Since the corona has been reported in Indonesia, it has a high-frequency coverage and always reported in the prime time and being headline news in 


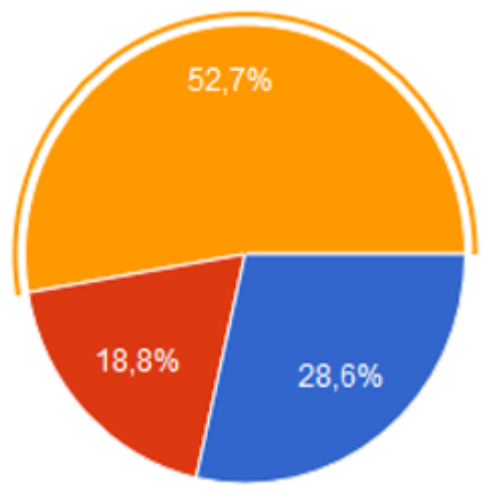

\section{- More than two hours \\ More than three hours \\ More than an hour}

FIGURE 3. The Duration of You Watch TV Every Day

various mass media. The frequency of the news and the high attention of society make this issue as popular news. Finally, the popularity of the news increase due to social media as the second source of information that spread it widely. A lot of modern society (social media users) do not want to miss the opportunity to be the first person to share information related to the Coronavirus through the status or the group chat on social media accounts whether in the form of images, texts, or videos. The high rate of information dissemination associated with the news of the Corona makes it always be the trending and popular on the page of social media status.

Based on FIGURE 3, on the survey that the researchers did on the condition of this pandemic showed that more people were watching via social media rather than $\mathrm{TV}$, the use of a TV in the pandemic was only about $52 \%$ of the community used media TV for 1 hour, and only 18.8 percent who watched it for 3 hours, the very low duration compared to social media.

Social Media has become a new way to disseminate the information related to the Coronavirus, the public reaction via social media was so intense and horrendous. It was known from the hashtag \#AwasHoaxVirusCorona which became one of the trending topics in the Twitter timeline. Based on the observation of Tekno Liputan6.com on Twitter, on Monday (3/2/2020), this purpose of this hashtag was to remind the community to not easily put trust in various information related to the Corona which was widely circulated in social media. Not only in the Twitter but also in Facebook and the WhatsApp as the popular social media used to write in the status column or spread the messages, images, videos on the group chat as the impact and reaction to the Corona dissemination from that they see, hear, or read in the media.

The reaction or response of netizens that were put in social media related to Covid-19 was different. The following was the opinion of one informant related to the impact of COVID-19 news dissemination on social media

"In my opinion, the information about corona in social media makes us feel anxiety, fear, and worry with our lives whether in terms of health, economic, or religious services" (Muhamad Alfian,2020).

Almost every day, it could be seen in the WhatsApp and Facebook status, people wrote about the corona. Some of them also posted images or videos, such as the video about how to prevent corona, news updates about the victims and the area that had growing number of the corona suspects, as well as the educational 
videos related to coronavirus.

The syndrome of using social media is like a virus that infects modern people. As social media becomes the most comfortable media used by society to communicate rather than to share their stories directly with the people around them. This is why the corona issue becomes increasingly popular, even people who do not watch the news on tv will know all about the Corona through social media.

\section{The Psychological Effect, Mental Disorders, Stress}

The psychological factor is one of the factors that affect media exposure. News related to government policy about the Corona Virus Disease (Covid-19), the lockdown and isolation policy as well as the increasing number of suspects becomes a trigger for the boredom, loneliness, anger, depression, and mental disorders, stress, psychological conditions that negatively make people more vulnerable to coronavirus. The highest frequency and duration of the news dissemination about the corona have produced obsessivecompulsive symptoms, a mental disorder that causes the sufferer to feel the urgency to act repeatedly. The mass media has led to increased anxiety and panic, it can be seen from the travel cancellation and the increasing number of visitors in hospitals, but the problem regarding the awareness of the danger of public concentration has not yet been realized (Mohamad \& Azlan, 2020).

One of the factors that affect the exposure of media on the public (media exposure) is the psychological condition of society. The society with this condition have increased levels of anxiety, many people worry about the health condition and the economy, around $37 \%$ of them worried about the health issues, but up to $36.6 \%$ worried about economic issues, make them experience the dilemma between working or staying at home.

Some of the significant factors in the level of frequency, duration, and usage of social media are the information, pleasure, and transaction factors. (Sopiah, (2013, June).) However, in corona virus news dissemination, psychological factor regarding the worried feeling on economy, health, jobs, and education as well as religion become the main factors that affect the level of social media usage (FIGURE 4).

\section{The Social Impact, Social Distancing, Panic Buying, Lockdown, Self- isolation}

Unstable economic conditions caused by media exposure, led to the increasing of public concern over the health conditions, including excessive protection on themselves, for example, washing hands repeatedly, cleaning home to avoid Corona Virus Disease 19 Covid-19. In the field of education,
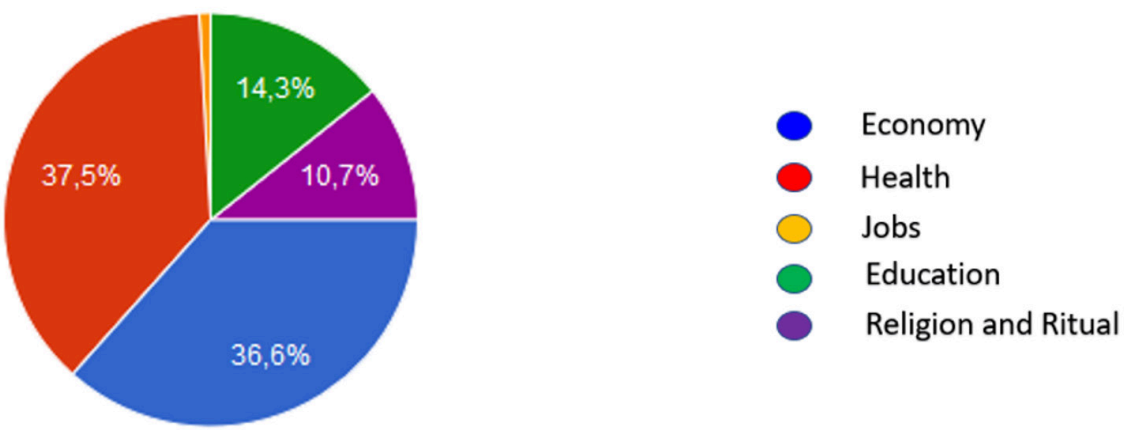

FIGURE 4. The Main Factors that Affect the Level of Social Media Usage 


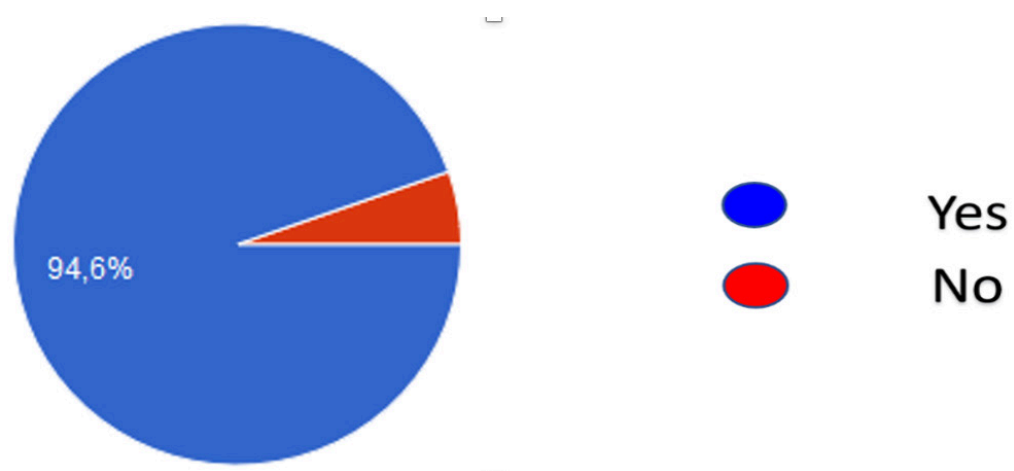

FIGURE 5. Data of Self-isolation at Home

university students have learned online, all social activity is done through online media, teaching by using social media, online media, the society started to adapt the e-learning process, for example, the use of Google Classroom, or learning through video conference, such as WebEx, and Google meet, one of the google apps. Teachers and lecturers whether they were the millennial generation or the old generation tried to force themselves to conduct online learning. One informant argued about online learning as follows:

"The condition during this pandemic forces society to adapt the online learning, despite many constraints, such as the limitations of the network, data packets, and technological devices (gadget)" (Ramli, 2020)

One of the implications of the coronavirus news exposure was the controversy of home-schooling among the parents and university students, many parents complained a lot about the severity in teaching their children, parents should replace the role of the teacher at home, students complained due to the severity of the tasks given by the lecturer. E-learning should be the alternative that makes learning more interesting. However, since the lack of preparation, online learning has led many teachers to assign an inappropriate amount of tasks. For example, reading the academic articles in every meeting, that can become a problem if on the same day three courses make students read three articles and answer the questions given by the lecturer. This activity is called the "work from home" or WFH and "School from home" or SFH, which means working and learning at home.

From the FIGURE 5, it can be seen that the social group or educated people that get the media exposure around $94,6 \%$ of them had isolated themselves at home, stay at home. The decision to stay at home was not based on the government and the priest's instruction, but the people in this educated social group understood the risk of COVID-19.

The use of social media affects the higher self-isolated behavior. The social media can shape the thinking way and culture as well as the social behavior of the community, and it can direct someone to be prosocial or antisocial. (Pandie, (2016))

\section{The Political Impact on Budget Policy}

The political campaign is no longer powerful for those who do not have a strategic role in the government. Candidates no longer meet directly with the voters, but for those who served in office, they can use their position to make policy. The increase and distribution of budgets to the regions to counteract the corona as the minister of the village did, that the village budget can be used to handle the corona in the village. 
Muhammad Qadaruddin Abdullah, dkk. The Agenda Setting of Corona...

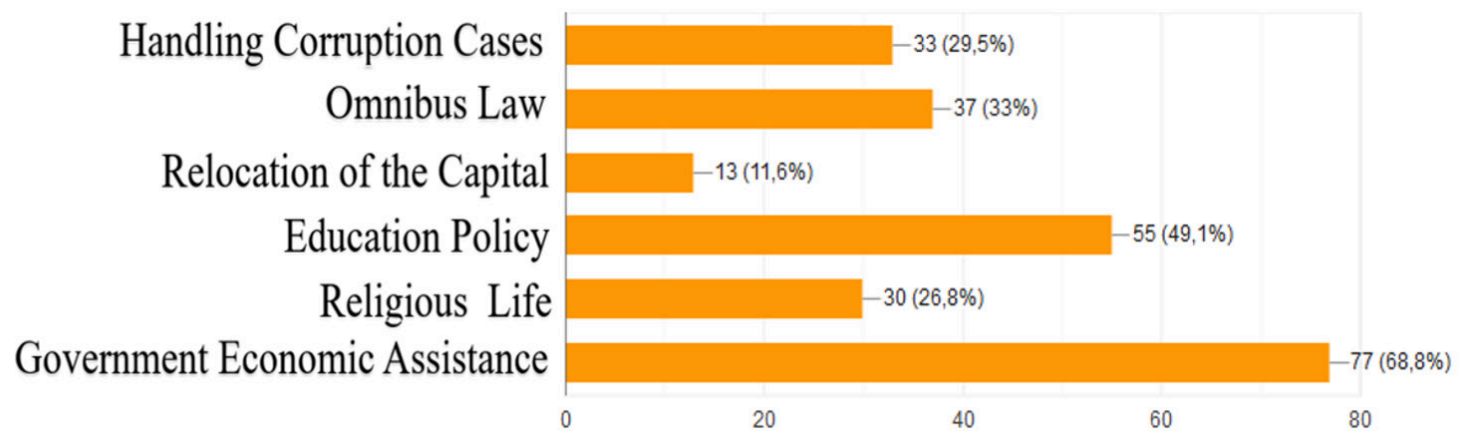

FIGURE 6. The Community was Aware of The Media Exposure

The FIGURE 6 explains that the community was aware of the media exposure that had hindered the dissemination of other important issues such as economic problems. Around $68.8 \%$ of the community considers economic issues was very important to be reported. Around 49,1\% related to education, $33 \%$ related to the law, $29 \%$ related to corruption, $26,8 \%$ related to religion, and $11.6 \%$ of the capital transfer. The complex issues in the community become the problems of society that cause people decided not to stay at home, not performed the regional quarantine, and also economic issues, religion, and some of the problems considered important by the community to be resolved for example the issue of education, the issue of moving the capital city.

The media agenda setting successfully diverted the issues on corruption, omnibus law, capital relocation, education and religious policies. The media production team considered the corona virus is the most important problem to be disseminate on news program and has the highest rate on news program. This made every media put their attention on the issues related to corona virus and only some of them raised the issues on corruption and legal cases. (https://binus.ac.id, 2020)

\section{The Impact of Religious Behavior, Selfishness in Practicing the Religion}

There were some phenomena related the religious practice during the pandemic, such as having a distance in prayer, no shaking hands after the congregational prayers, each congregation participants should bring their praying mat, the adhan wording changed from let prayer to be prayer at home, and also the instruction not need to have a congregation prayer in the mosque. The government policy and the fatwa from the Council of Indonesian Ulama (MUI) related to the congregational prayer and the Friday prayer at home that become a controversy among Muslims.

The circular of MUI Fatwa was clearly stated that the gathered has the negative aspects, which essentially instruct people not to become a victim or spread the harm to others, Surah alBaqarah: 196 stated that "Do not put yourself into a destruction" as well as in Surah an-Nisa verse: 9 which stated, "Do not kill yourself". Corona is not visible, but it has enormous impacts. If the corona appears like a beast, then surely a lot of people will run away from the virus.

Mufti and mullah continuously urge and preach by using a social media, build awareness of the people to be obedient to the Fatwa of the Mufti, but still many Muslims considered their area in the safe category, no one is exposed to the corona, whereas if we follow the detail information in some social media, the coronavirus symptoms are difficult to detect directly.

From the FIGURE 7, it appears that 


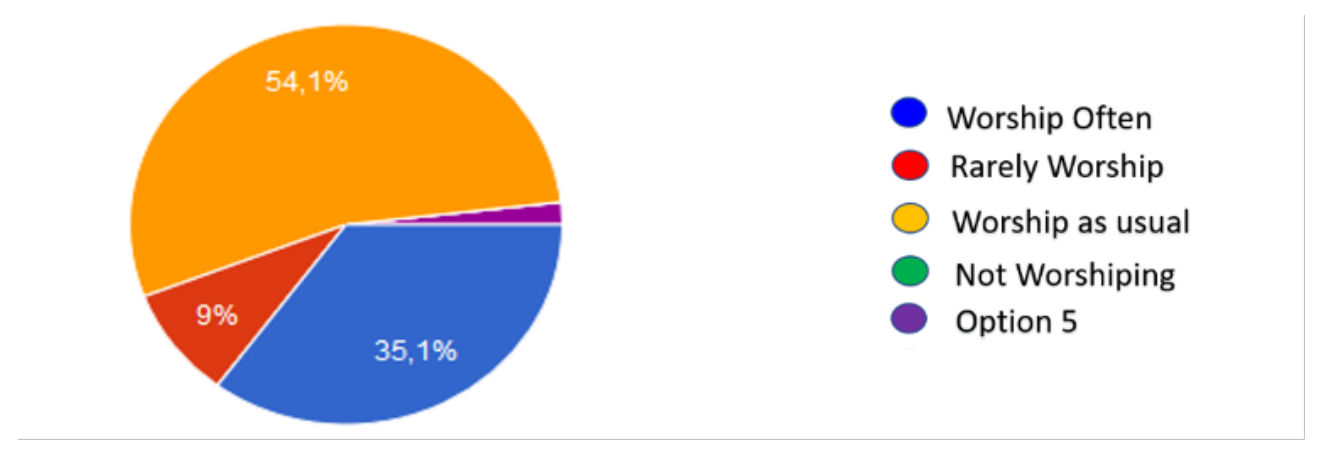

FIGURE 7. The Crucial Factors Affecting The Media Exposure

there were about $54,1 \%$ which indicates that the belief or religion factor was one of the crucial factors affecting the media exposure. There are about $54.1 \%$ of respondents did the worship as usual in the mosque and $35.1 \%$ of them often did the worship in the mosque or keep in the congregation in the mosque showing the high level of egoism in practicing the religion affecting the media exposure. The egoism in practicing the religion is comparable to have a religion without the knowledge about it, which can result in harm. Considers himself pious, diligent prayer, and a good monotheism practices that led him not to have any effort in avoiding corona anymore. This is different from the events experienced by the prophets, due to their faith in God, they were given miracles. For example, Prophet Isa was able to restore the life of the dead, The Prophet Ibrahim was not consumed by fire, the Prophet Yunus get into the belly of the fish, and so on.

\section{CONCLUSION}

The spreading information of Covid-19 on Social Media and TV make people anxious about their health, the economy, religion, and education. Thus, the community is experiencing a dilemma between staying at home or going to work since the economic problems is a very important issue. Therefore, the community has great expectations related to the budget policy that the community does not experience economic anxiety. This researched identified the gap between the level of exposure on the higher news dissemination of Covid-19 and the public information satisfactory. In other words, as one of the information sources, the government has not been able to provide the information needed by the community. Besides, the massive and continuous dissemination of information on television and social media about the corona has diverted the public from other political issues such as corruption and the legislative process of laws and regulations. The reality regarding this information is in line with the agenda setting that believes on political agenda of using the media to control the public opinion.

\section{REFERENCES}

Amala, I. (2019). Pengaruh Terpaan Pemberitaan Media Online Tentang Sandiaga Uno Terhadap Sikap Masyarakat (Survey Terhadap Masyarakat Kelurahan Baru Depok). Universitas Pembangunan Nasional Veteran.

Ansor. (2011). Teori Agenda Setting dan Citra Diri Pemerintah Analisis Pemberitaan orupsi dan Penurunan Pemerintahan SBY. JURNAL KOMUNIASI, 5(2), 145-156.

Datubara, B., \& Irwansyah, I. (2019). Instagram TV: Konvergensi Penyiaran Digital dan Media Sosial. Mediator: Jurnal Komunikasi, 12(2), 251-263. doi:https://doi. 
org/10.29313/mediator.v12i2.4778

Denis, M. (1997). Audience Analysis . SAGE Publishing.

Erika, D. (2011). Komunikasi dan Media Sosial (Communication and Social Media). The Messenger, III.

Hayat, N. (2019). Komunikasi Politik. Makassar: Pilar Nusantara.

https://binus.ac.id. (2020). teori agenda setting dan framing dalam media relations

Ilham, F. H. (2014). Pengaruh Terpaan Pemberitaan Politik di Media Online dan Terpaan Iklan kampanye Politik di Media Televisi Terhadap Elektabilitas Partai Hanura. Interaksi Online.

Kamil, I. (2018). Peran Komunikasi Pemerintahan dalam PenangananLingkungan Kumuh . Mediator: Jurnal Komunikasi, 11(1), 129-139.

Kriyantono, R. (2008). Teknik Riset Komunikasi: Disertai Contoh Pratis Riset Media, Public Relation, Advertising, Komunikasi Pemasaran. Jakarta: Kencana Prenada Media Group.

Lexy, M. (2010). Metodologi Penelitian Kualitatif (Revisi ed.). Bandung: PT: Remaha Rosdakarya.

LittleJohn, S. W. (1996). Theories of Human Communication Terjemahan Edisi Indonesia. Jakarta: Salemba Humanika.

Munawwaroh, P. R. (2017). Pengaruh Terpaan Media Pada Akun Instagram@Exploresiak Terhadap Minat Kunjungan Wisata Ke Siak Sri Indrapura. (Doctoral dissertation, Riau University).

Mohamad, E. \& Azlan, A. A. (2020). COVID-19 and communication planning for health emergencies. Jurnal Komunikasi: Malaysia Journal of Communication, 36(1).

Mulyana, D. (2007). Metode penelitian komunikasi. Contoh-Contoh Penelitian Kualitatif Dengan Pendekatan Praktis. Bandung:
Rosdakarya.

Mustika, T. \&. (2019). Pengaruh Terpaan Media Terhadap Reputasi Lembaga Pemerintah. Inter Script: Jurnal Of Creative Communication, 1.

Natalia, M. (2017). Agenda Setting Berita Pedofilia di Samarinda Pos. eJournal Ilmu Komunikasi. Fisip-Ummul, 5, 283-295.

Nugroho, Y. A. (2015). Televisi Indonesia: Dinamika Struktur dan Khalayak. Jakarta: Centre For Innovation Policy and Governance, University of Manchester, Fprd Foundation Indonesia.

Pandie, M. M. ((2016)). Pengaruh Cyberbullying di Media Sosial terhadap perilaku reaktif sebagai pelaku maupun sebagai korban cyberbullying pada siswa kristen SMP Nasional Makassar. Jurnal Jaffray, 43-62.

Perse, E. M. (2001). Media Effects and Society. England: Routledge.

Puji, R. (2016). Media Baru, Visi Khalayak Aktif dan Urgensi Literasi Media. Jurnal Komunikasi, 1.

Rahadi, D. R. (2017). Perilau Pengguna dan Informasi Hoax di Media Sosial. Manajemen dan ewirausahaan, 5.

Rulli, N. (2018). Khalayak Media Identitas, Ideologi, Perilaku pada Era Digital.

Sopiah, N. (2013, June). Faktor-faktor yang mempengaruhi penggunaan Media Facebook. In Seminar Nasional Aplikasi Teknologi Informasi (SNATI), (Vol. 1, No. 1).

Sugiyono, P. (2013). Cara Mudah Menyusun Skripsi (Doctoral Dissertation, Tesis, dan Disertasi. Bandung: Alfabete .

Widiastuti, S. P. (2017). Pengaruh Media Exposure dan Kepemilikan Asing Terhadap Corporate Social Responsibility Expenditure dan Corporate Social Responsibility Disclosure (Studi Empiris pada Seluruh Perusahaan yang. Reviu Akuntansi dan BisnisIndonesia, 7889. 